\title{
Lica i naličja hrvatske ideologije
}

\author{
Vjeran KATUNARIĆ
}

Odjel za sociologiju, Sveučilište u Zadru

vjeran.katunaric@zg.t-com.hr

- Ivo Paić. Imati Hrvatsku: paradoks jednoga obećanja. Zagreb: Naklada Jesenski i Turk, 2011, 364 str.

Klasa, kojoj stoje na raspolaganju sredstva za materijalnu proizvodnju, raspolaže samim tim i sredstvima za duhovnu proizvodnju [...] Vladajuće misli nisu ništa drugo do idealni izraz vladajućih materijalnih odnosa [...]

(Marx i Engels, 1989: 393-394)

\section{Vladajuće misli na »kraju povijesti«}

Za većinu ljudi u Hrvatskoj još uvijek može skandalozno zvučati tvrdnja da je Hrvatska žrtva vlastitih »vladajućih misli«: ideologijskih konstrukcija koje prikrivaju odnose moći u hrvatskom društvu između vladajuće elite i ostatka društva. Za razliku od ideologijskih konstrukcija koje simbolički integriraju društvo, vladajući svojom politikom cijepaju društvo i onesposobljuju ga da se dostojanstveno nosi s novim centrifugalnim silama koje proizvodi globalni kapitalizam. Hrvatska se, poput mnogih drugih zemalja »tranzicije«, premjestila iz jednoga u drugi imperij, iz socijalističkoga s politbiroima u kapitalistički s financijskim stožerima, podjednako nedohvatljivima građanima (ili možda opet podanicima?). Imperij tako nije samo nadnacionalna, nego i u neku ruku nadljudska tvorevina, koju je Simmel označio kao neuračunljivo ostvarenje naših želja: »Pred nama su bezbrojne objektivacije [...], carstva kojima se upravlja kao po njihovim vlastitim zakonima i koja traže da budu sadržaj i norma naše individualne egzistencije koja zapravo ne zna što bi s njima [..., bezoblična beskonačnost koja stupa pred pojedinca zahtijevajući od njega da je prihvati« (Simmel, 2001: 73).

Uočljiva je sličnost između više razina neuračunljivih »objektivacija« u imperijalizmu, pa tako i između globalizirajućeg kapitalizma i hrvatske želje za samostalnošću utjelovljene u Republici Hrvatskoj. Obje tvorevine podjednako su izmaknule kontroli većine ljudi na koje se odnose. Također nedostaje odgovarajućeg objašnjenja povezanosti kapitalizma i imaginativnih sadržaja koji se rađaju u njegovim postojećim jedinicama, nacionalnim državama. U njima nedostaje i pravo samorazumijevanje. U Hrvatskoj, na primjer, ubrzano raste broj gubitnika posla 
tako i drugih životnih šansi, koji razumiju kako, ali ne razumiju zbog čega im se to dogodilo. Središnji ideologem, ${ }^{1}$ stvoren 1992. godine (»Imamo [...] Hrvatsku. Bit će onakva kakvu sami želimo [...]«) pripada kategoriji »vladajućih misli« čija objektivacija izgleda groteskno, ali samo u odnosu na polaznu predodžbu, a izgleda »realno« budući da Hrvatsku danas »posjeduju« skupine koje nemaju zajednički naziv, nego se još uvijek pozivaju na šire referentne skupine. Kad je riječ o Hrvatima u toj skupini, njihov broj u odnosu na maksimalan broj odraslih i radno sposobnih Hrvata iznosi nekoliko postotaka, ali je moć te manjine s obzirom na prihode i utjecaj u društvu, uključujući samopredstavljanja Hrvatima kao svojom širom obitelji, mnogostruko veća nego ostalih članova društva.

Što se zaista dogodilo? Na to pitanje, inače temeljno u historiografiji, nije lako odgovoriti. Danas je, doduše, skoro svima u Hrvatskoj bjelodano da ona nije suverena zemlja. Preciznije, Hrvatska nema suverenost (u nizu najvažnijih područja, od financija do vojne sfere), nego ima autonomiju u smislu provođenja zakona ili pravila na svom teritoriju (usp. Held, 1990). Glavninu zakonodavstva danas sačinjavaju dijelovi pravne stečevine EU, čije učinke na socioekonomsko stanje u zemlji vlada može kontrolirati, ali ne i preinačiti u korist većine (ne)zaposlenih. ${ }^{2}$

Postavlja se pitanje zbog čega je velik dio naroda prihvatio iluzornu predodžbu o »vlastitoj« državi koja će udovoljiti njihovim potrebama i željama. I zbog čega još i danas radnici koji gube posao, uvjereni, kako izjavljuju, da su izigrani, nisu načistu s tim tko ih je (sve) prevario i zbog čega. Radnici također nisu spremni priznati vlastiti udio u velikom (samo)zavaravanju, nego još uvijek radije vide agresora na Hrvatsku kroz prizmu binarnih arhetipova o Hrvatima i Srbima. Do sada najiscrpnije i u mnogome najvjerodostojnije tumačenje ideologema »Imamo Hrvatsku« pruža knjiga Ive Paića Imati Hrvatsku: paradoks jednoga obećanja (Zagreb: Jesenski i Turk, 2011). Autor u knjizi skida sloj po sloj značenja s te poruke da bi je ogolio do njezine cinične srži. Njegova analiza nije formalna ni sustavna, nego esejistički eliptična. Glavne ideje provlače se kroz brojne fragmente, mini eseje, i granaju k različitim referentnim okvirima i autorima. Njegovu ćemo interpretaciju o povezanosti nacionalizma i kapitalizma u slučaju Hrvatske pokušati razumjeti u cjelini, ali i s izvjesnim kritičkim odmakom i potrebom za razmatranjem jednoga »dopunskog« sadržaja kad je riječ o iluzornim obećanjima.

Knjiga ima vrlo širok teorijski (od modernističkih klasika, poput Nietzschea i Marxa, do postmodernističke i postkolonijalne kritike kapitalizma) i epistemološki raspon (uvidom u tumačenja povijesne prekretnice, koju naziva Situacijom, iz

\footnotetext{
${ }^{1}$ Ideologem je neka vrsta reprezentativnog uzorka ideologije. Prema Fredericu Jamesonu, koji je uveo taj termin, ideologem je »najmanja [...] jedinica u biti antagonističkih kolektivnih diskursa društvenih klasa«, koja se također pojavljuje u obliku "protonarativa« (prve, polazne priče) (Jameson, 1981: 76, 115). Dio Tuđmanova govora iz 1992. (vidjeti naprijed u tekstu) u kojem se pojavljuje znakovit izraz »Imamo Hrvatsku«, može se uzeti kao primjer protonarativa u novoj Hrvatskoj.

${ }^{2}$ Zakon o radu praktično je posljednje područje u kojem je hrvatska vlada donekle odolijevala pritiscima za liberalizacijom i deregulacijom.
} 
rakursa različitih disciplina, od filozofije povijesti preko lingvistike do lacanovske psihoanalize). Pritom se isprepleću dva polja argumentacije. Prvo je, najveće kako po teorijskoj važnosti tako i zapremnini u knjizi, hermeneutičko s gusto istkanim pojmovljem poglavito postmodernističke provenijencije. ${ }^{3}$ Izjava »Imamo Hrvatsku«, iznesena na početku nove hrvatske vlasti, glavni je predmet analize obuhvaćen nizom teorijskih argumenata, kako vlastitih tako i brojnih drugih autora. U tom sklopu Paić također kritički analizira pretvorbu spomenutog iskaza u medijskom diskursu, zapravo jednom, tipično površno provedenom, novinskom ispitivanju javnog mnijenja u kojem se anketiranjem građana pokušalo izraz »imati Hrvatsku« prikazati ne kao metodološki artefakt nego kao čvrsti dio nacionalne svijesti, glavnu »preokupaciju« čak 77\% građana (Paić, 2011: 36-42).

Drugo polje argumentacije formalno bi pripadalo u kritiku političke ekonomije, odnosno marksističku interpretaciju kapitalističke ekonomije kao vladajućeg oblika klasne vladavine u suvremenoj civilizaciji. U sadržajnom smislu, pak, takva interpretacija u knjizi čini korak dalje ususret postmodernističkom razumijevanju ekonomskog diskursa i ekonomske politike neoliberalizma (Paić tumači Marxa u ključu Badioua pa rad smatra sastavnim dijelom kapitala). U provincijskoj nemoći Hrvatske pred pobjedonosnim hodom zapadnog kapitalizma Paić pronalazi glavni razlog samoidealizacije Hrvatske. Takvo objašnjenje je relevantno, ali se čini nedovoljnim. Na primjer, nije objašnjeno zbog čega se iluzija kojom se pokazuje (ne) moć hrvatske vlasti da rješava nadolazeće društveno-ekonomske probleme još uvijek žilavo opire racionalnoj argumentaciji i široj perspektivi (na primjer, da sukob najprije s drugima radi obrane zemlje, a potom sukob vlasti /državnih i privatnih poslodavaca/ s radnicima nisu odvojene nego poglavlja iste priče) $?^{4}$

Jedan od razloga te nedorečenosti valja tražiti u suvremenoj kritičkoj literaturi o kapitalizmu. U njoj je očito presahnulo vrelo nadahnuća kojim je Marx, dijelom i Lenjin, zamišljao pobjedonosnu borbu proletarijata protiv kapitalizma u krilu malih ili potlačenih naroda (na primjer Poljske, u Marxovu, i baltičkih naroda $\mathrm{u}$ Lenjinovu slučaju). Štoviše, Paić, poput nekih drugih autora slične provenijencije, ne objašnjava samo nastanak nego i razvojne putanje nacija, uključujući hrvatsku tranziciju, kao tvorbe proizišle iz diktature kapitala. Diktatura kapitala, tako strogo deterministički pojmljena, trebala bi lako stvoriti globalni melting pot u čijem bi vrtlogu većina nacija prestala postojati kao jasno omeđeni entiteti iz postojeće epohe nacionalnih država. Umjesto toga, svijetom bi kapital neometano cirkulirao i proizvodio »kolateralne štete« u tradicionalnim prostorima država-članica UN-a još uvijek ponosnih na svoje »posjede«. U takvoj perspektivi i Hrvatska bi se po-

\footnotetext{
${ }^{3}$ Argumentacijskih nijansi ima toliko mnogo i raznolikih, referenci također, da ih nije lako identificirati kao dijelove iste (teorijske) cjeline. Stoga i ovaj osvrt predstavlja samo jedan od mogućih pokušaja razumijevanja glavnih ideja u knjizi, ponajprije ideje o ukrštanju puteva nacionalizma i kapitalizma u Hrvatskoj.

${ }^{4}$ I u literaturi o nacionalizmu relativno je malo radova koji upućuju na povezanost etničkih/nacionalnih sukoba i strategijskih interesa novoformirane kapitalističke klase na Istoku (usp. Woodward, 1995; Katunarić, 2003).
} 
našala kao jedna od stotinjak privremenih kapitalističkih uporišta koji se podižu i rasklapaju poput planinarskih šatora.

Takvu krajnju posljedicu nije, dakako, moguće dokazati pa to ne čini ni Paić, nego iznosi opća razmišljanja o kapitalističkoj ekonomiji iz postmodernističke perspektive. Kapital tako izgleda kao planetarni stroj (u starijoj kritičkoj literaturi bio je »poludjeli slon«) koji usisava sve pred sobom. Po uzoru na Badioua Paić ekonomski determinizam označava kao mehanizam homogenizacije i cirkulacije kapitala u različitim nacionalnim prostorima. To ćemo gledište kritički razmotriti ne samo zato što je manje uvjerljivo od Paićeve dekonstrukcije hrvatskih ideoloških izričaja, nego i stoga što interpretativna veza između obaju fenomena, hrvatskog nacionalizma i (centrifugirajućeg učinka) kapitala, nije, čini nam se tako, dovoljno artikulirana.

Da bismo tu primjedbu potkrijepili, najprije ćemo sažeto prikazati glavne argumente u Paićevoj knjizi i razmotriti koliko su isprepleteni kulturološki (opis elemenata hrvatskog identiteta) i politekonomski sadržaji (opis dinamike liberalnog kapitalizma) pogodni za objašnjenje koristi koju nacionalizam ima od kapitalizma i obratno. Izvjesna nedorečenost u tom pogledu nije samo Paićev nego i širi problem. Tako je među suvremenim teorijskim strujama u marksizmu, koje se bave objašnjenjem utjecaja medija (posredno uzrocima pobjede kapitalizma nad socijalizmom), došlo do bitnog razilaženja u interpretaciji. Jedna struja, kulturalistička (bliska glavnini kulturnih studija), govori o kulturnoj hegemoniji kao autonomnoj sili, smatrajući je važnijom od ekonomske ili političke hegemonije. Druga, gramscijevska (bliska klasičnom marksizmu i klasnoj analizi) govori o kulturnoj hegemoniji kao sastavnom dijelu ekonomske hegemonije vladajuće klase (usp. Kellner, 2004). Premda se potonje gledište ne bi moglo nedvosmisleno primijeniti na Hrvatsku s početka 1990-ih, budući da se njezina kapitalistička klasa još nije bila formirala, ipak je njezina prethodnica iz redova političkih mešetara s društvenomdržavnom imovinom pripremila teren tako što je najprije namirila svoje želje, a odmah potom otvorila vrata ulasku inozemnog kapitala. ${ }^{5}$

O formiranju vladajućeg stratuma u Hrvatskoj Paić piše fragmentarno, najviše u fusnotama. ${ }^{6} \mathrm{~Pa}$ ipak, neke se spone između ideologijskog diskursa hrvatske vlasti i njezine ekonomske politike mogu nazrijeti iz Paićeva poimanja funkcija ideologije. Tako ideologem o difuznom »posjedovanju« Hrvatske prikazuje, s jedne strane, kao zamagljivača ekonomske stvarnosti, ponajprije situacije ljudskog rada (i radnika), kao njezina camera obscura, između ostalog kao "privid [...] brige za naše»

\footnotetext{
${ }^{5}$ Izraz »strani kapital« odbojan je zbog više razloga, a najviše zbog toga što kapital baš i nema domovinu i nije istina da »domaći« kapital po pravilu ima više obzira od »stranog« prema lokalnim radnicima i stanovništvu. Možda bi trebao imati, ali tada više to ne bi bio isti kapital (sjetimo se upozorenja iz Marxova Kapitala, prema kojem »samilosni« kapitalist neminovno propada).

${ }^{6}$ Fusnote u knjizi sadržavaju malo bogatstvo faktografskih bilježaka i komentara, ali i razgovijetnu konzistentnost i komunikativnost, izvjesnu obzirnost, prema čitateljima koji su manje upoznati s (meta)teorijama jezika i Derridinim dekonstrukcionizmom, na primjer.
} 
(Paić, 2011: 196). Takvo označavanje blisko je pejorativnom značenju ideologije kao lažne svijesti. No, Paić radije barata širim pojmom ideologije, kao »aparatom države« (poput Althussera, po kojem je ideologija »imaginarna reprezentacija stvarnih uvjeta egzistencije«/Paić, 2011: 85/). Taj oblik svijesti i institucije doduše ne razotkriva postojeću društvenu stvarnost kao neodrživu i ne radi protiv nje, nego je legitimira i opslužuje razlozima kao najbolju ili pak jedino moguću. U većem dijelu knjige Paić proširuje pojam ideologije u duhu postmodernizma koji odbacuje značenje ideologije kao »lažne svijesti«. Slično Žižeku, Debordu i drugima, Paić ideologiju označava kao realnu konstrukciju društvene stvarnosti (vidjeti sličnu kritiku poimanja ideologije kao »lažne svijesti«, osobito izoštrenu i diferenciranu s obzirom na poimanje znanosti, u: Kalanj, 2010). I kapitalizam je, dakako, ideologija, danas dominirajuća, a od početka u savezništvu s dobrim dijelom ekonomske znanosti pa je suvišno isticati da takva ideologija konstituira suvremeni svijet. Osim toga, ocrtavajući načelne razlike između desnih i lijevih ideologija u Hrvatskoj, Paić upozorava kako se te razlike sve više gube. Odatle izvodi opći zaključak da »kazivanje [...] potiskuje dokazivanje« (Paić, 2011: 88).

Postaje li konačno ideologija univerzalnim sadržajem svih znanja i (do)kazivanja, uključujući znanstveni ili filozofijski diskurs? Da bi se uklonio prijeteći reductio ad absurdum u takvom razmišljanju potrebno je naći mjeru, zapravo povlačiti nove granice između više ili manje ideologiziranih diskursa, prije svega kad je riječ o znanstvenim i političkim tekstovima. Postmodernistički pristup dovodi u pitanje historiografsku i općenito znanstvenu objektivnost i proglašava je samo jednom od legitimnih pripovijesti, a ne više jedino ispravnom (usp. Gross, 2009; Repina, 2010). Zato se nanovo postavlja pitanje (pomicanja) granice između ideologije i znanosti. To pitanje ne bi samo po sebi bilo problematično da knjiga predstavlja samo opću teorijsku raspravu. Ona je, međutim, najviše usredotočena na razumijevanje ideološkog izričaja u Hrvatskoj, gdje se ideologija u tako proširenom formatu pojavljuje kao explanandum i explanans, jednom kao klupko nebuloza o trenutku osjećaja »apsolutne slobode« Hrvatske, Situacije, a drugi put u obliku analize koja ispod površine ideologijskog konstrukta nalazi čvrstu interesnu jezgru, a to je »mi« koji se od nacionalnog volumena, prenapuhanog željama, na koncu sveo na političku elitu Hrvatske.

Pretpostavljamo da se u takvoj preraspodjeli ideologijskih koeficijenata na temelju čega se može govoriti o manjem koeficijentu političkih pristranosti u znanstvenom diskursu i obratno, manjem koeficijentu znanstvene objektivnosti u političkim ideologijama - uspostavlja teorijsko polazište Paićeva djela. On pokušava objasniti način na koji kapital vlada Hrvatskom s pomoću njezinih vlastitih ideoloških konstrukata. U tom smislu valjalo bi pobliže odrediti o kojim se (sve) ideološkim konstruktima radi. Na primjer, možda je jednostavno krupni kapital mogao lakše »zaposjednuti« Hrvatsku ili koju drugu postjugoslavensku državu ekonomski oslabljenu i više ili manje iscrpljenu ratom - nego bivšu jugoslavensku federaciju u cjelini?

Paić iznosi općenitu tvrdnju da je nacionalna homogenizacija u režiji političke elite povezana s ekonomskom homogenizacijom u režiji kapitala. Pretpostav- 
ljamo da bi u cilju objašnjenja te povezanosti možda trebalo promotriti i jedno drugo žarište kolektivne iluzije o "posjedovanju« Hrvatske, koje ne izvire toliko iz identitetske priče koliko iz socijalno-ekonomskih frustracija. To je slika potrošačkog raja. S mnogo strana, od trgovina Trsta, Graza, Atene i obližnjih mjesta uz jugoslavenske granice sa Zapadom, kao i zapadnih televizijskih postaja, slika Zapada kao ekonomije obilja prodrla je u svijest Hrvata, Srba, Slovenaca, Albanaca, i drugih jugoslavenskih naroda. Daljnje otvaranje prema zapadnom svijetu, doživljenom prima facie, vodilo je preko Hrvatske kao »obećane zemlje«, ali pod uvjetom, kao najvažnije, razvrgnuća veza s ostalim republikama i uspostave samostalne države. ${ }^{7}$

Najvažnije je imati na umu da je nacionalizam ključni ideološki prijenosni mehanizam iz svijeta realnog socijalizma u svijet kapitalizma (i njime uvjetovane demokracije, »realne demokracije«). U tom prijenosu nije prenesen baš »privid« o samostalnoj državi, budući da je samostalnost Hrvatske u neku ruku ostvarena (kroz autonomiju bez suverenosti). Istodobno, vjerojatno je bilo prividno bogatstvo koje bi se na trenutak bilo stvorilo putem masovnog posjedovanja vlasničkih dionica, vaučerskom privatizacijom. Ona bi, po svoj prilici, ubrzo okopnjela zbog relativnog siromaštva dioničara koji bi, kao »rajski sanjari«, rado odmah prodali svoje dionice.

Nacionalizam je, dakle, na ovaj ili onaj način bio ključna karika u prihvaćanju kapitalizma (iako ne i glavni uzrok propasti socijalizma). U vezi s tim valja razmotriti sljedeće autorove tvrdnje. Prvo, da je »hrvatski [...] narod s drugim narodima na tlu dovršena kapitalskoga osvajanja Zemlje«. Osim toga, budući da nedostaje valjana razvojna alternativa, autor skupa s Badiouom zaključuje da je nakon pada Berlinskog zida došlo do općega misaonog nazadovanja: kritika kapitalizma nije više sposobna zamisliti dostojnu alternativu kapitalizmu, osim u žanru znanstvene fantastike (Paić, 2011: 293; usp. Suvin, 2010). Nadalje upućuje na to da Hrvatska nije zemlja razvijenoga građanskog društva i razvijenog oblika kapitalizma, nego zemlja u kojoj cinična elita uvodi »sirovi kapitalizam« i masama poručuje: »Htjeli ste kapitalizam, sada ga imate!«. Štoviše, ni radništvo, prema njegovu mišljenju, ne vidi u kapitalizmu svog neprijatelja, nego, naprotiv, agitira u korist razvijenog kapitalizma koji bi prevladao »sirovi kapitalizam« (usp. Paić, 2011: 78-79). Ovdje zbunjuju dvije autorove tvrdnje. Prva, da su radnici u Hrvatskoj (bili i ostali) pobornici kapitalizma. Valja sumnjati da za to ima valjanih dokaza u situaciji kada radnici nisu imali drugog izbora. S druge strane, bili su bez sumnje impresionirani obećavajućim potrošačkim šarenilom zapadnog kapitalizma, za što je trebalo steći odgovarajuću kupovnu moć. To im, međutim, hrvatski kapitalizam nije omogućio, a ni zapadni radnicima iz perifernih zemalja više ne nudi nove poslove kao šezdesetih i sedamdesetih godina 20. stoljeća.

\footnotetext{
${ }^{7}$ Teško je ustvrditi nudi li Paić u raspletanju argumenta o naravi želje, kao temeljnoj kategoriji u zamišljanju Hrvatske, i elemente za sagledavanje uloge »iluzorne potrošnje« u tom zamišljanju. Kako bilo, međutim, držimo da je »iluzorna potrošnja« komplementarna njegovoj interpretaciji odnosa između nacionalizma i kapitalizma.
} 
Drugo što zbunjuje jest izraz »razvijeni kapitalizam«. Pod njim Piać vjerojatno podrazumijeva zapadni kapitalizam iz sedamdesetih i osamdesetih godina 20. stoljeća s jakim elementima socijalne države ili možda suvremeni skandinavski (uključujući i australski i kanadski, na primjer). Danas »razvijeni« kapitalizam, u smislu ekonomskog rasta koji uglavnom podrazumijeva rast profita na račun smanjenja troškova za plaće (radnika), akumulira sve više bogatstva u rukama sve manjeg broja ljudi i, obratno, oduzima sredstva i osiromašuje sve veći broj ljudi, uključujući ovaj put i najrazvijenije kapitalističke zemlje (v. Dale, 2012). Tako kapitalizam postaje sve »sirovijim« sa sve više elemenata (neo)feudalizma (usp. Katunarić, 2010).

Pogledajmo sada pobliže kako Paić povezuje homogenizirajuće sile nacionalizma i kapitalizma da bismo, ponešto odstupajući od autorova izbora najjačeg žarišta nove hrvatske ideologije, mogli razaznati obrise »potrošačkog raja,$^{8} \gg$ »komunalnih nebesa (Castells, 2002), čime nacionalizam, kao i neoliberalizam, pokušava sekularizirati sadržaje tradicionalnih religijskih predodžaba o »raju«.

\section{Obećana zemlja kao »psihička stvarnost»}

Udaljivši se od zapažanja na temelju klasičnih teorija politike i demokracije, prema kojima se Hrvatska nalazi u »pretpolitičkom« stanju, ponajprije zato što njezini povijesni, pretežno etnički, rascjepi onemogućuju funkcionalne sukobe svojstvene (liberalnoj) demokraciji (v. na primjer: Malović, 2011), Paić poseže za (postmodernističkom) teorijom »postpolitike«, prema kojoj je Hrvatska preuređena u »postpolitički« prostor: »Signalne riječi i govor tijela postpolitike ne podnose nacionalne i demokratske strateške programe i njihove nabačaje na prostor 'slobodne' igre spiniranja i njena zamaha proteklih pet-šest godina. Ta se igra istim intenzitetom nastavlja, i dalje se građane nastoji priviknuti na nju, pripitomiti ih tako da logiku stvaranja brendova u ekonomiji, prihvate kao samu logiku političkog « (Paić, 2011: 165).

Zapažanje o »spinovima« koji zamjenjuju javno argumentiranje na izvjestan se način nastavlja na mitsko ishodište nove Hrvatske, što ga reprezentira govor Franje Tuđmana izgovoren odmah nakon priznanja Hrvatske, u kojem se nalazi sljedeća signalna rečenica: »Imamo svoju Hrvatsku. Bit će onakva kakvu sami želimo i nećemo nikomu dopustiti sa strane da nam propisuje kakva ta Hrvatska treba da bude« (Paić, 2011: 13, fusnota 1).

Tuđmanova rečenica nije, doduše, pravi spin, budući da ništa ne konfabulira, nego u stilu demijurga, kako kaže Paić, proglašava posve novu epohu u kojoj je izborena nevjerojatna sloboda kolektivnog izbora. Odatle se otvara jedan drugi prostor. To je prostor želje koja ne korespondira ni sa kakvom drugom zbiljom nego svojom, kao »psihička stvarnost«: »Kažu li volim Hrvatsku, zapravo su rekli: volim svoju želju«, ističe autor parafrazirajući jednu Nietzscheovu misao (Paić, 2011: 79). Teško je prikazati sve načine na koje Paić rastavlja glavni ideološki konstrukt,

\footnotetext{
${ }^{8}$ Sjetimo se Đodanovih predviđanja o skorašnjih »pet tisuća maraka« mjesečno u svakoj »hrvatskoj lisnici«.
} 
od psihoanalitičkog do čisto ironičnog u vezi s tim kako je tko naumio raspolagati Hrvatskom. Čitatelj može doista uživati u autorovoj misaonoj i jezičnoj razigranosti s implikacijama lako danog obećanja. Tako razotkriva svjetove života obećanja, njegove svjetove - mogućeg bez budućnosti, ideologije pripitomljavanja, »obećanja u tragovima « i pacifikacije očekivanja (to su i neki od podnaslova prvog poglavlja knjige); slijede izrazi »brige za naše«, privrženosti i ljubavi (poglavlje s petnaest duhovito naslovljenih varijacija na temu ljubavi: od demijurga »posve novoga« do »Domovino, tko te najviše voli?«), iza čega slijedi niz bravuroznih interpretacije o identitetu pod naslovom »Ptolomejski svijet Mi-identiteta«: od homogenog i egoističnog Mi do prijetvornosti u dogovaranju (u čemu se dade prepoznati i notorna hrvatska »figa u džepu«, ovaj put na račun vlastitog projekta »zadanog kretanja«).

Na kraju knjige Paić se ne pita »Što se zapravo dogodilo?«, budući da ovo nije historiografska knjiga s Rankeovim metodološkim načelom (»wie es eigentlich gewesen«), nego se pita »Što smo to zapravo doživjeli?«. Kao da se sve zbivalo u nekom drugom, sanjanom svijetu. U takvom se pomaku prema oniričkom dade prepoznati »kulturni obrat« kao zaštitni znak postmoderne reinterpretacije povijesnih sadržaja u smislu »nove kulturne povijesti« (usp. Repina, 2010). Dakako, dvadesetak godina nove Hrvatske nismo doslovno prespavali. Ali smo zato proživjeli (i nekako uspjeli preživjeti) ostvarenje snova »sanjača« koji u Hrvatskoj više nije toliko omiljen. Ti su snovi, zaključuje Paić, plod mašte svih onih koji su u »vremenu-prostoru 'kraja povijesti' [željeli] imati Hrvatsku« (Paić, 2011: 341). Tog su se epohalnog posjeda ipak neki uspjeli dokopati, zapravo relativno malo njih, o čijim karakternim crtama, interesima i stvarnim naumima njihova nacionalna pripadnost ništa ne govori.

Mitotvornost u pretpolitičkom »demijurškom« prostoru, koja je Hrvatskoj svojedobno dala potisnu snagu, u današnjem je "postpolitičkom« prostoru marginalizirana. To je postao dobrim dijelom kapitalistički prostor, koji se širi i koji umjesto nacionalnih, putem fleksibilizacije tržišta rada, ucrtava unutrašnje granice između bogate manjine i osiromašene većine, koje se provlače čitavim svijetom, lako prelazeći preko svih državnih granica. Narod je stoga razočaran, »nezahvalan narod« (Paićev izraz), to više nije isti narod što se tiče želja i očekivanja. U njemu sve više raste broj ljudi alergičnih kako na demokraciju, odnosno političku participaciju, tako i tržišnu ekonomiju. ${ }^{9}$ Stvara li se masovna baza za neki novi antidemokratski pokret?

Moramo li još uvijek »sanjati« svoju perspektivu da bi se otvorio neki horizont nade što nadilazi komodificirani postpolitički prostor nacije? Snaga iluzije o nacionalnoj (sve)moći vjerojatno ne bi bila tako velika da nije bila značajno

\footnotetext{
${ }^{9}$ Prema jednom istraživanju u Ukrajini, povećava se, mnogo brže nego ostale kategorije nacionalnog identiteta (»građanski«, »etnički« $\mathrm{i} » h i b r i d n i \ll)$, kategorija »atomizirani identitet«. To su građani koji odbijaju tržište i demokratske reforme, kao i bilo koji oblik javne ili političke participacije (Hansen i Hesli, 2009). Vjerojatno je udio te kategorije povećan i u Hrvatskoj, uključujući takve među apstinentima od referenduma u Hrvatskoj o ulasku u EU.
} 
uvećana iznevjeravanjem obećanja »pretpolitičkog« prostora u bivšem socijalizmu koji je jedinu šansu radnicima za stjecanjem bitno većih prihoda pružio otvaranjem granica za rad u zemljama razvijenog kapitalizma. Ispražnjeni prostor želja iz socijalizma narod je popunio djetinjastim željama spram kapitalizma, kao beskonačnim konzumom roba i usluga (sve skupljih i nedostupnijih u ostvarenom kapitalizmu). $\mathrm{Ne}$ zaboravimo onu scenu neposredno nakon pada Berlinskog zida, kad su stanovnici Istočnog Berlina u dugoj povorci ušli u Zapadni Berlin, lica zadivljenih šarenilom svjetlećih reklama i izlozima trgovina.

\section{Kapitalističko preuzimanje obećane zemlje}

Paićeva knjiga nema pojmovno kazalo, što je razumljivo s obzirom na pojmovnoterminološku gustoću teksta koja bi takvo kazalo učinila preglomaznim. To otežava rekonstrukciju autorove politekonomske tematike, razasute u manjim fragmentima u cijeloj knjizi, pa ćemo se osloniti na epilog knjige u kojem su sažeto izneseni glavna tema i argumenti (Paić, 2011: 333-337). Glavna je tema međuzavisnost »kapitalske i nacionalne homogenizacije«. Ta je međuzavisnost protumačena kao odnos između dinamičnog procesa i statičnog elementa, jednog koji cirkulira i drugog koji miruje u svojoj esencijalnosti. Iz tog proturječja slijedi »borba suprotnosti« u kojoj kapital, kao nadmoćna sila, razara tkivo nacije: »Nacije su izložene uniformnim povlasticama tržišta i žele mu biti izložene te tako pripadati 'artikuliranoj cjelini' kapitalske logike opće ekvivalentnosti, identitetske kulture i kulturne logike kolektiviteta. [...] Kao apstraktna, homogenizacija stvara cjelinu raščlanjivanjem 'tri logike': ekvivalentnosti, identiteta i zajednice. [...] Želja za izloženošću povlasticama tržišta izlaže identitet nacije i nacionalne države zahtjevima cirkuliranja, a liberalno kapitalističko desolidariziranje intervenira u solidarnost zajednice« (Paić, 2011: 336-337).

Apstrahirajući narav homogenizacijskih procesa autor i glavne pojmove, tržište i nacija i njihove atribute, predstavlja na idealtipski način. Bilo bi također potrebno, možda i važnije, ustanoviti varijacije koje otkrivaju naličja obiju ideologija, neoliberalne koja putem svojih racionalizatora u ekonomskoj znanosti tržište prikazuje kroz apstraktne modele, tj. idealizirane slike postojeće ekonomske stvarnosti, ali ne i stvarne situacije i uglavnom štetne učinke tih modela: tržište baš i nije slijepa sila. Slično je s nacijom, bolje rečeno nacijama koje nisu sve $\mathrm{u}$ istom položaju u odnosu na veliki kapital. Kad bi kojim slučajem i došlo do brisanja nacionalnih granica i bitnog slabljenja ili potpunog nestanka nacionalnih država, taj proces zacijelo ne bi zahvatio sve ili barem ne podjednako sve države. U globalnoj centrifugi mogu oslabiti pa i nestati male ili (vojno i ekonomski) slabije države, na što upućuju današnje tendencije jačanja nekih i slabljenja većine drugih država. ${ }^{10}$ Općenito, globalizirajućem kapitalu odgovara svijet bez granica, ali samo kao sfera neometanog protoka. Nikako mu ne odgovara slobodan pro-

\footnotetext{
${ }^{10}$ Neoliberalne parole o smanjenju troškova za financiranje države ostale su samo parole. Troškovi za vojsku, ali i neke druge javne sektore, povećali su se u SAD-u i drugim razvijenim zemljama (v. Navarro, 2006; Iversen, 2005).
} 
tok ljudi (neometana seoba sa svjetskog Juga vjerojatno bi potrošila financijske resurse država Sjevera).

U spomenutom odlomku također upada u oči tvrdnja da nacije »žele da budu izložene« tržištima i njihovim povlasticama. To bi opet valjalo razložiti izvan okvira metodološkog nacionalizma gdje se nacije uzimaju kao homogene i samodovoljne jedinice analize, a i s obzirom na vrste tržišta. Može se pretpostaviti da se radnici ne žele izlagati prevelikim rizicima konkurencije na tržištima rada, ali svakako žele raditi na poslovima koji donose pristojne prihode, poput nekadašnjih gastarbajtera. U većini zemalja, uključujući Hrvatsku, regularna tržišta rada danas ne otvaraju takve mogućnosti. Osim toga, suvremena kapitalistička ekonomija zanemaruje sektor industrijskog rada u korist financijskog sektora odakle špekulativnim igrama iscrpljuje realni sektor, dok istodobno posuđuje novac uz visoku kamatu, što malo koji dužnik uspijeva vraćati. No, mamac postaje neodoljivim ne samo zato što omogućuje veću kupovnu moć i potrošnju, nego i zato što malo tko može išta značajno kupiti bez dizanja kredita, tj. duga. Za vraćanje duga najčešće je nužno, pogotovo kad je riječ o većim dužnicima, kao što su poduzeća ili države, podizati novi kredit itd. Stoga se Paić opravdano poigrava značenjima funkcija moderne ekonomije kapitalizma. One manje odgovaraju potrebama ljudi, a mnogo više njihovim iluzijama time što raspaljuju njihove želje. Ta činjenica zadovoljenje potreba čini praktički nemogućim. ${ }^{11} \mathrm{U}$ tom iluzionizmu moguće je naći i žarište iluzije o Hrvatskoj kao »obećanoj zemlji«.

Narativni obrazac te želje može se opisati ovako: Kapitalistička Hrvatska, ali samo pod uvjetom da je nezavisna (od Jugoslavije), proizvest će svoj komad raja na Zemlji. Iste, Paićevim terminima, signalne riječi svojedobno su bile istisnute iz političke »psihičke stvarnosti« i upisane kao nesuđeni turistički slogan Hrvatske. U takvom zamišljanju nema mjesta, kako bi rekao Weber, racionalnoj ekonomiji, nego želji koja se ponaša poput, ponovo parafrazirajući Webera, karizmatika ${ }^{12} \mathrm{u}$ ekstazi, tj. neracionalno i rastrošno. Već je Kolumbo bio uvjeren da je u Americi otkrio »obećanu zemlju« (četiri rajske rijeke iz Knjige postanka). U svođenju ekonomije na njezine funkcije unutar »psihičke stvarnosti«, među želje mase nesretnika koji prolaze pokraj raskošno aranžiranih izloga dućana u kojima ne mogu gotovo ništa kupiti (ta paklenska muka realni je antipod rajskoj ekonomiji), ogleda se šira relevantnost Paićeve interpretacije Hrvatske kao predmeta želja.

Unatoč svemu, Paić vidi izlaz iz začaranog kruga želja. Zaključuje da treba ponajprije promijeniti odnos prema hrvatskoj nacionalnoj prošlosti i istom odbaciti

${ }^{11}$ Želje su prenapuhane potrebe koje se ostvarenjem pretvaraju u potrebe koje su isto toliko »realne« kao i osnovne potrebe. Na tržnici kupujemo ono što nam je u osnovi potrebno, budući da višak (obično hrane) brzo propada. U velikim trgovinama kupujemo dosta suvišnoga, ali ipak željenoga. Vjerojatno će tako biti sve dok u drugim ljudima ne otkrijemo mnogo toga zanimljivijega nego u stvarima, dok s drugima ne razmijenimo ono što nama nedostaje, kao i oni s nama.

${ }^{12}$ Tipično je za karizmatske vođe da zanemaruju ekonomsku racionalnost i, ne pitajući za cijenu, nemilice troše (usp. Weber, 1968). 
stari mit o »obećanoj zemlji« čije ostvarenje produbljuje, umjesto da premošćuje, socioekonomski jaz u društvu, koji sve više na pozornicu, namjesto građana, uvodi nove plemiće i podanike. Na jednom mjestu u knjizi, nimalo slučajno, Paić prepoznaje glavne metafore hrvatske državotvorne politike kao oznake feudalizma. Zajednička im je »Zvonimirova kruna«. Ispod krune su metafore glave (vladara) i tijela (homogeniziranog naroda). Zabrinuto se pitamo, skupa s Paićem, ostvaruje li hrvatska država putem ekonomskog rasta koji nagrađuje sve manji broj ljudi, upravo taj mit iz doba društvenih »stališa« europskoga kasnog feudalizma i ranoga novog vijeka, čiji se geopolitički krajolik sastoji od niza vojno-policijskih ispostava za zaštitu vrhova društava kraljevina i kneževina s blagoslovom Crkve. Pokušajmo se skupa s autorom nadati nečemu drugome s pretpostavkom, koja nadu zasniva na analogiji, naime da farsa, kao tragikomična dramska vrsta, ne traje dugo ni na povijesnoj pozornici. Dakako, pod uvjetom da je naš javni politički teatar prožet demokratskim etosom i odgovarajućim društvenim senzibilitetom koji ne podnosi krajnosti i velike udaljenosti među pripadnicima istog društva, koji gradi javni prostor nasuprot nekomunikativnim svjetovima privatnih prostora $\mathrm{s}$ vanjskim svijetom spojenih putem medija. U takvim se prostorima proizvode ljudski dvojnici koji ne podnose ljudsku blizinu i dodir. »Obećana zemlja« i slični mitemi nastali su u sličnim prostorima svijesti i ostvarivali su se obrušavanjem na vanjsku stvarnost, nasilno i bezobzirno. U takvoj izvedbi glavni akteri podjednako duboko zaziru od »njihovih« i »naših« ljudi.

\section{LITERATURA}

Castells, Manuel (2002 [1997]). Moć identiteta. Zagreb: Golden marketing.

Dale, Gareth (2012). »Double movements and pendular forces: Polanyian perspectives on the neoliberal age«, Current Sociology, 60 (1): 3-27. doi:10.1177/ 0011392111426645

Gross, Mirjana (2009). »Dekonstrukcija historije ili svijet bez prošlosti«, Historijski zbornik, 62 (1): 165-194.

Hansen, Holley E. i Hesli, Vicki L. (2009). »National Identity: Civic, Ethnic, Hybrid, and Atomised Individuals«, Europe-Asia Studies, 61 (1): 1-28. doi:10.1080/ 09668130802532894

Held, David (1990). Modeli demokracije. Zagreb: Školska knjiga.

Iversen, Torben (2005). Capitalism, Democracy, and Welfare. Cambridge: Cambridge University Press.

Jameson, Frederic (1981). The Political Unconscious: Narrative as a Socially Symbolic Act. Ithaca, N. Y.: Cornell University Press.

Kalanj, Rade (2010). Ideologija, utopija, moć. Zagreb: Naklada Jesenski i Turk i Hrvatsko sociološko društvo.

Katunarić, Vjeran (2003). Sporna zajednica: novije teorije o naciji i nacionalizmu. Zagreb: Naklada Jesenski i Turk i Hrvatsko sociološko društvo.

Katunarić, Vjeran (2010). »Razvoj ljudske suradnje: prema postmonetarnom društvu?«, Revija za sociologiju, 40 (2): 129-155. 
Kellner, Douglas [2004]. »Cultural Marxism and Cultural Studies«, http://pages. gseis.ucla.edu/faculty/kellner/essays/culturalmarxism.pdf.

Malović, Nenad (2011). »Elementi hrvatske društveno-političke scene u svjetlu načela supsidijarnosti«, Bogoslovska smotra, 81 (4): 955-964.

Marx, Karl i Engels, Friedrich (1989 [1845-1846/1932/]). Njemačka ideologija (Prvi dio), u: Karl Marx i Friedrich Engels. Rani radovi. 9. izd. Zagreb: Naprijed, str. 355-428.

Navarro, Vincente (2006). »The Worldwide Class Struggle«, Monthly Review, 58 (4), http://www.monthlyreview.org/2006/09/01/the-worldwide-class-struggle.

Paić, Ivo (2011). Imati Hrvatsku: paradoks jednoga obećanja. Zagreb: Naklada Jesenski i Turk.

Repina, Lorina P. (2010). »Historical Memory and Contemporary Historical Scholarship«, Russian Studies in History, 49 (1): 8-25. doi:10.2753/RSH10611983490101

Simmel, Georg (2001 [1917]). »Kriza kulture«, u: Georg Simmel. Kontrapunkti kulture (ur. Vjeran Katunarić). Zagreb: Naklada Jesenski i Turk i Hrvatsko sociološko društvo, str. 72-86.

Suvin, Darko (2010). Defined by a Hollow: Essays on Utopia, Science Fiction and Political Epistemology. Oxford: Peter Lang.

Weber, Max (1968). On Charisma and Institution Building (ur. S. N. Eisenstadt). Chicago: University of Chicago Press.

Woodward, Susan L. (1995). Balkan Tragedy: Chaos and Dissolution after the Cold War. Washington, D.C.: The Brookings Institution. 